\title{
PENGARUH DISIPLIN DAN MOTIVASI KERJA TERHADAP KINERJA KARYAWAN PADA PT. FUSE NANO TEKNO JAKARTA BARAT
}

\author{
${ }^{1}$ Michael Woerdianto, ${ }^{2 *}$ Bachtiar Arifudin Husain \\ Universitas Pamulang, Tangerang Selatan, Banten, Indonesia \\ *dosen01773@unpam.ac.id
}

\begin{abstract}
Abstrak
Penelitian ini bertujuan untuk mengetahui pengaruh disiplin dan motivasi terhadap kinerja karyawan pada PT. Fuse Nano Tekno Jakarta Barat. Dalam penelitian ini metode yang di gunakan adalah metode asosiatif kuantitati dengan pengujian hipotesis,sedangkan untuk mendapatkan data di lakukan dengan menyebar kuesioner kepada 80 responden. Berdasarkan hasil penelitian, menunjukkan bahwa disiplin dan motivasi kerja berpengaruh positif terhadap kinerja karyawan dengan persamaan regresi $Y=10,867+0,379(X 1)+0.351(X 2)$. Hasil analisis regresi menunjukkan bahwa koefisien disiplin sebesar 10,867 dan motivasi sebesar 0,351 bertanda positif. Semakin baik disiplin yang dijalankan maka akan semakin baik pula kinerja karyawan. Demikian pula dengan motivasi. Kontribusi pengaruh disiplin dan motivasi adalah sebesar 0.639 atau $63,9 \%$. Dari pengujian hipotesis menggunakan uji statistik $\mathrm{t}$ hitung $=(6,827>1,9912)$ Thitung $>$ Ttabel. Sehingga H0 ditolak dan H1 diterima. Artinya terdapat pengaruh positif dan signifikan secara simultan antara disiplin dan motivasi terhadap kinerja karyawan.
\end{abstract}

Kata Kunci: Disiplin, Motivasi, Kinerja Karyawan

\section{Abstract}

This study aims to see the influence of enthusiasm and motivation on employee performance at PT. Fuse Nano Tekno. In this research, the method used is the quantitative associative method with hypothesis testing, while to obtain the data is done with spread out questionnaires to 80 respondents. Based on the research results, it shows that discipline and work motivation have a positive effect on employee performance with the regression equation $Y=10.867+0.379(\mathrm{X} 1)+0.351(\mathrm{X} 2)$. The results of the regression analysis show that the discipline coefficient is 10.867 and the motivation is 0.351 which is positive. The better the discipline that is carried out, the better the employee's performance will be. Likevwise with motivation. The contribution of the influence of discipline and motivation amounted to 0.639 or $63.9 \%$. From testing the hypothesis using the statistical test $t$ count $=(6.827>$ 1.9912) Tcount> Ttable. So that HO is rejected and H1 is accepted. This means that there is a positive and significant influence simultaneously between discipline and motivation on employee performance.

Keywords: Discipline, Motivation, Employee Performance

\section{PENDAHULUAN}

Pengembangan Sumber Daya Manusia (SDM) merupakan cara perusahaan agar dapat mempertahankan eksistensi kerja semua komponen perusahaan. Sebuah perusahaan harus mampu mengoptimalkan kemampuan sumber daya manusia yang dimilikinya agar pencapaian sasaran dapat terlaksana, namun hal tersebut tidaklah sederhana perlu pemahaman yang baik tentang perusahaan, perlu ada strategi pengembangan yang matang agar SDM yang dimiliki sebuah perusahaan terpakai sesuai kebutuhan.

Sumber daya manusia sebagai salah satu unsur dalam perusahaan dapat diartikan sebagai manusia yang bekerja dalam suatu perusahaan. SDM dapat disebut juga sebagai personil, tenaga kerja, pekerja,karyawan, potensi manusiawi sebagai penggerak perusahaan dalam mewujudkan eksistensi perusahaan.

Wether dan Davis (1996) dalam sutrisno (2016:4), menyatakan bahwa sumber daya manusia adalah "pegawai yang siap, mampu, dan siaga dalam 
mencapai tujuan-tujuan organisasi", (Sutrisno, 2016:4). Manajemen Sumber Daya Manusia merupakan bagian dari manajemen perusahaan yang memfokuskan diri pada unsur sumber daya manusia. Manajemen sumber daya manusia mempunyai tugas untuk mengelola unsur manusia secara baik agar diperoleh tenaga kerja yang puas akan pekerjaannya.

Disiplin kerja dapat dilihat sebagai sesuatu yang besar manfaatnya, baik bagi kepentingan perusahaan maupun bagi para karyawan. Bagi perusahaan adanya disiplin kerja akan menjamin terpeliharanya tata tertib dan kelancaran pelaksanaan tugas, sehingga diperoleh hasil yang maksimal. Adapun bagi karyawan akan diperoleh suasana kerja yang menyenangkan sehingga akan menambah semangat kerja dalam melaksanakan pekerjaannya. Dengan demikian, karyawan dapat melaksanakan tugas nya dengan penuh kesadaran serta dapat mengembangkan tenaga dan pikiran semaksimal mungkin dengan terwujudnya tujuan perusahaan. Jika lingkungan kerja semua nya disiplin maka seorang karyawan akan ikut disiplin,tetapi jika lingkungan kerja perusahaan tidak disiplin, maka seorang karyawan juga akan ikut tidak disiplin. Untuk itu sangat sulit bagi lingkungan kerja yang tidak disiplin tapi ingin menerapkan kedisiplina, karena lingkungan kerja akan menjadi panutan para karyawan.

Hasibuan (2016: 115) mengemukakan bahwa disiplin kerja adalah kesadaran dan kesediaan seseorang dalam mentaati semua peraturan perusahaan dan norma-norma sosial yang berlaku. Kesadaran adalah sikap seseorang yang secara sukarela menaati semua peraturan dan sadar akan tugas dan tanggung jawabnya. Jadi dia akan mematuhi atau mengerjakan semua tugasnya dengan baik, bukan atas paksaan. Kesediaan adalah suatu sikap, tingkah laku dan perbuatan seseorang yang sesuai dengan peraturan perusahaan, baik tertulis maupun tidak.

Disiplin diartikan apabila karyawan selalu datang dan pulang tepat waktu, mengerjakan semua pekerjaannya dengan baik, mematuhi seluruh peraturan perusahaan dan norma-norma sosial yang berlaku. Tanpa displin karyawan yang baik, sulit bagi institusi mencapai hasil yang optimal. Disiplin yang baik mencerminkan besarnya rasa tanggung jawab seseorang terhadap tugas-tugas yang diberikan kepadanya. Hal ini untuk mendorong gairah kerja, semangat kerja dan terwujudnya tujuan institusi, karyawan dan masyarakat. Sementara faktor disiplin dapat dilihat dari absensi kerja karyawan (Menurut Drs. H. Malayu S.P. Hasibuan (2016).

Demikian halnya dengan PT. Fuse Nano Tekno perusahaan yang bergerak di bidang jasa broker asuransi dengan menggunakan system aplikasi yang modern dan canggih, dimana para konsumen dapat membeli asuransi yang diinginkan melalui aplikasi fuse pro, PT. Fuse Nano Tekno sendiri beralamt di Jalan Meruya Ilir Raya, Ruko Rich Palace Blok C1 Srengseng Jakarta Barat. Saat ini PT. Fuse Nano Tekno mempunyai karyawan yang terdiri dari Direktur, Manajer Marketing, Supervisor Marketing, Staff Marketing dan Admin operational. Waktu kerja dimulai dari jam 9 pagi sampai dengan jam 6 sore dengan waktu istirahat selama 1 jam dari jam 12 sampai dengan jam 1 siang. Adapun masalah-masalah yang menyangkut disiplin, motivasi dan kinerja yang saat ini ada di PT. Fuse Nano Tekno perlu mendapat perhatian adalah mengenai disiplin karyawan dalam kehadiran kerja dan disiplin waktu kerja. Disiplin di PT. Fuse Nano Tekno begitu baik menurut penulis perusaahan tidak menjalankan jam kerja sesuai dengan prosedur, sehingga banyaknya karyawan yang sering datang terlambat, beberapa karyawan yang tidak patuh pada peraturan, banyaknya karyawan yang sering absen di jam operasional kerja.

Disiplin kerja dan Motivasi kinerja karyawan pada PT. Fuse Nano Tekno belum maksimal sehingga penulis menemukan pengaruh dari disiplin dimana karyawan memiliki semangat kerja yang menurun dan kurangnya tanggung jawab 
karyawan pada tanggung jawab pekerjaan yang sudah diberikan. Tingkat absensi menurun karena kurangnya disiplin sehingga karyawan banyak yang melakukan pelanggaran-pelanggaran seperti datang terlambat, alpha dan hal ini akan berdampak kepada kinerja karyawan.

Motivasi kerja menjadi pendorong seseorang melaksanakan suatu kegiatan guna mendapat hasil yang terbaik. Oleh karena itulah tidak heran jika karyawan yang mempunyai motivasi kerja yang tinggi biasanya mempunyai kinerja yang tinggi pula. Untuk itu motivasi kerja karyawan perlu ditingkatkan agar karyawan dapat menghasilkan kinerja yang terbaik. Selain itu juga jika ada seorang karyawan dengan keadaan posisi yang kurang semangat terhadap pekerjaan maka perlu adanya sikap perhatian yang diberikan terhadap pemimpin untuk memotivasi karyawan tersebut.

Motivasi kerja adalah keadaan kejiwaan dan sikap mental manusia yang memberikan energi, mendorong kegiatan atau gerakan dan mengarah atau menyalurkan perilaku kearah mencapai kebutuhan yang memberi kepuasan atau mengurangi ketidak seimbangan. Oleh karena itu,motivasi kerja dapat diartikan sebagai bagian integral dari hubungan/industrial dalam rangka proses pembinaan, pengembangan dan pengarahan sumber daya manusia dalam suatu perusahaan. Menurut (Wibowo, 2016) motivasi kerja bisa didefinisikan sebagai perilaku yang berorientasi tujuan. Memotivasi ialah mengajak karyawan mengikuti kemauan untuk menyelesaikan tugas.

Kualitas kerja karyawan setiap bulan menurun dikarenakan pengaruh dari kurangnya motivasi,sebagai seorang pelaku usaha,salah satu poin penting yang tak boleh luput dari perhatian kita adalah menjaga motivasi kerja para karyawan. Poin ini terbilang sangat penting,mengingat baik buruknya kinerja karyawan akan berimbas pada perusahaan yang dijalankan,ketika motivasi kerja karyawan menurun,bisa dipastikan bila roda perusahaan juga tidak bias berjalan dengan seimbang. Begitu juga sebaliknya,bila motivasi kerja karyawan bias terjaga dengan baik,maka perkembangan perusahaan akan bisa berjalan dengan lancar kebijakan lainya yang dilakukan perusahaan dalam meningkatkan kinerja karyawan dan dilakukan dengan memberikan fasilitas bagi karyawan dalam upaya memberikan motivasi dan kepuasan kerja dalam upaya peningkatan kinerja karyawan yang lebih baik lagi.

Menurut Afandi (2018:83) Kinerja adalah hasil kerja yang dapat dicapai oleh seseorang atau kelompok orang dalam suatu perusahaan sesuai dengan wewenang dan tanggung jawab masing-masing dalam upaya pencapaian tujuan organisasi secara illegal, tidak melanggar hukum dan tidak bertentangan dengan moral dan etika.

Suatu perusahaan dibentuk untuk mencapai tujuan bersama, namun untuk mencapai tujuan secara efektif diperlukan manajemen yang baik dan benar. Oleh karena itu, PT. Fuse Nano Tekno tidak terlepas dari peran sumber daya didalamnya. Kinerja sebagai sesuatu yang tampak, yaitu individu relevan dengan tujuan perusahaan.

Kinerja yang baik merupakan salah satu sasaran perusahaan dalam mencapai produktivitas kerja yang tinggi. Tercapainya kinerja yang baik tidak terlepas dari kualitas sumber daya manusia baik pula. Oleh karena itu, baik perusahaan kecil ataupun besar sangat membutuhkan hasil kinerja seorang karyawan yang mempunyai semangat tinggi dalam bekerja, karena dengan hasil kinerja yang baik, perusahaan akan bisa meningkatkan keuntungan dan meningkatkan prestasi kerja, dan produktivitas kerja. Untuk meningkatkan kinerja karyawan maka dalam pelaksanaanya dibutuhkan disiplin kerja yang sangat tinggi. Selalu memperhatikan tingkat absensi kehadiran, agar tidak terjadi hal-hal yang akan merugikan perushaan dan diri kita sendiri.

Penilaian yang dilakukan oleh masing-masing divisi Manager yang kemudian dikumpulkan pada Humen 
Resources Department (HRD) secara keseluruhan menunjukan bahwa dari komponen Pengetahuan Pekerjaan hanya mampu mencapai 63\%, Administrasi 64\%, Kualitas Kerja 66\%, Kuantitas Kerja 46\%, Disiplin $68 \%$, Berhubungan dengan User $73 \%$, Integritas 24\%, Komunikasi 49\%, Kerjasama 55\%, Inisiatif 54\%, Kemampuan Beradaptasi 96\%, Kreativitas 39\%. Dari pencapaian kriteria penilaian pada PT. Fuse Nano Tekno di simpulkan bahwa dari tahun 2020 dapat dilihat bahwa kinerja karyawan rata - rata tinggi di kategori baik. Adapun kekurangan tersebut masih dapat di perbaiki kinerja karyawan pada PT. Fuse Nano Tekno, dari informasi yang diberikan oleh HRD bahwa realisasi pencapaian kinerja karyawan dapat di simpulkan belum optimal karena belum memenuhi target dan harapan yang ditetapkan PT. Fuse Nano Tekno.

Berdasarkan uraian diatas, penulis tertarik untuk melakukan penelitian dengan judul "Pengaruh Disiplin Dan Motivasi Kerja Terhadap Kinerja Karyawan Pada PT. Fuse Nano Tekno Jakarta Barat".

\section{TINJAUAN PUSTAKA}

1. Disiplin

Menurut Veithzal Rivai (2015:825), disiplin kerja adalah suatu alat yang digunakan para manajer untuk berkomunikasi dengan karyawan agar mereka bersedia untuk mengubah suatu perilaku sebagai suatu upaya untuk meningkatkan kesadaran dan kesedian seseorang mematuhi semua peraturan perusahaan dan norma-norma sosial yang berlaku.

Menurut S.P. Hasibuan (2016:193), menjelaskan bahwa disiplinan adalah kesadaran dan kesediaan seseorang menaati semua peraturan perusahaan dan norma-norma sosial yang berlaku. Kesadaran adalah sikap seseorang yang secara sukarela menaati semua peraturan dan sadar akan tugas dan tanggung jawabnya. Jadi, dia akan mematuhi/mengerjakan semua tugasnya dengan baik, bukan atas paksaan. Sedangka kesediaan tersebut adalah suatu sikap, tingkah laku, dan perbuatan seseorang yang sesuai dengan peraturan perusahaan, baik yang tertulis maupun tidak.

Berdasarkan beberapa pendapat tersebut dapat diambil kesimpulan bahwa disiplin merupakan sikap atau perilaku ketaatan seseorang atau sekelompok orang yang sesuai prosedur serta terhadap peraturan baik secara tertulis maupun tidak tertulis, yang tercermin dalam bentuk tingkah laku dan perbuatan. Dengan ditetapkannya peraturan tertulis maupun tidak tertulis diharapkan agar para karyawan memiliki sikap disiplin yang tinggi dalam bekerja, sehingga produktivitas kerja meningkat.

2. Motivasi

Menurut Malayu S.P. Hasibuan (2017:143) motivasi adalah pemberian daya penggerak yang menciptakan kegairahan kerja seseorang agar mereka mau bekerja sama, bekerja efektif dan terintegrasi dengan segala daya upayanya untuk mencapai kepuasan.

Menurut Winardi mengemukakan (2016:6) bahwa motivasi merupakan suatu kekuatan potensial yang ada di dalam diri seorang manusia, yang dapat dikembangkannya sendiri atau dikembangkan oleh sejumlah kekuatan luar yang pada intinya berkisar sekitar imbalan moneter dan imbalan non moneter, yang dapat mempengaruhi hasil kinerjanya secara positif atau negatif.

Menurut Winardi mengemukakan (2016:6) bahwa motivasi merupakan suatu kekuatan potensial yang ada di dalam diri seorang manusia, yang dapat dikembangkannya sendiri atau dikembangkan oleh sejumlah kekuatan luar yang pada intinya berkisar sekitar imbalan moneter dan imbalan non moneter, yang dapat mempengaruhi hasil kinerjanya secara positif atau negatif.

Sedangkan yang dikemukakan oleh Malayu (2015:23) pengertian 
motivasi adalah mempersoalkan bagaimana cara mendorong gairah kerja bawahan, agar mereka mau bekerja keras dengan memberikan semua kemampuan dan keterampilan untuk mewujudkan tujuan perusahaan

Dari definisi di atas, maka motivasi dapat disimpulkan debagai hal yang sangat penting dalam setiap usaha / kelompok yang bekerja sama untuk mencapai tujuan / organisasi, di satu pihak ada yang menganggap itu adalah simpel karena pada dasarnya manusia mudah di motivasi, dengan memberikan apa yang diinginkannya. Di lain pihak motivasi di anggap kompleks, karena di anggap penting bagi sebagian orang sehingga perlu mendapatkan kajian yang lebih mendalam

Motivasi yang ada pada diri seseorang merupakan pendorong yang akan mewujudkan suatu perilaku guna mencapai tujuan kepuasan dirinya. Orang mau bekerja memenuhi kebutuhan, baik kebutuhan yang disadari (Consious needs) maupun kebutuhan/keinginan yang tidak disadari (Unconscious needs); demikian juga orang mau bekerja untuk mendapatkan kebutuhan fisik dan mental.

\section{Kinerja}

Pengertian kinerja merupakan suatu yang dinilai dari apa yang dilakukan oleh seorang karyawan. Dalam kerjanya dengan kata lain, kinerja individu adalah bagaimana seorang karyawan melaksanakan pekerjaannya atau untuk kerjanya. Kinerja karyawan yang meningkat akan mempengaruhi atau meningkatkan prestasi organisasi sehingga tujuan organisasi yang ada ditentukan dapat dicapai. Berikut ini adalah definisi-definisi tentang kinerja karyawan menurut para ahi :

Menurut Mangkunegara (2015:67) Kinerja merupakan jawaban dari berhasil atau tidaknya tujuan organisasi yang telah ditetapkan. Para atasan atau manajer sering tidak memperhatikan kecuali sudah amat buruk atau segala sesuatu jadi serba salah. Terlalu sering manajer tidak mengetahui betapa buruknya kinerja telah merosot sehingga perusahaan atau instansi menghadapi krisis yang serius.

Menurut Mangkunegara (2016:67) Pengertian kinerja adalah hasil kerja secara kualitas dan kuantitas yang dicapai oleh seorang pegawai dalam melaksanakan tugasnya sesuai dengan tanggung jawab yang diberikan kepadanya.

Menurut Edison,dkk (2016: 190) Kinerja adalah hasil dari suatu proses yang mengacu dan diukur selama periode waktu tertentu berdasarkan ketentuan atau kesepatakan yang telah ditetapkan sebelumnya.

Menurut Marwansyah (2016:229) Kinerja adalah pencapaian atau prestasi seseorang yang berkenan dengan tugastugas dibebakan kepadanya.

Menurut Amir dalam (Masrukin, Hubeis, \& Wijayanto, 2018) berpendapat bahwa kinerja adalah prilaku atau kegiatan yang ditampilkan oleh seseorang dalam kaitan dengan tugas kinerja perusahaan, dalam rangka menghasilkan sesuatu yang bermakna bagi organisasi, masyarakat luas atau bagi diri sendiri dan orang sekitar.

\section{METODE}

Penelitian ini dilaksanakan di PT. Fuse Nano Tekno Tekno yang beralamt di Jalan. Meruya Ilir Raya, Ruko Rich Palace Blok B-1 Srengseng Jakarta Barat. Waktu Penelitian ini dilaksanakan selama 4 (delapan) bulan yang dimulai dari bulan Desember 2020 - Maret 2021.

Populasi dalam penelitian populasinya adalah karyawan PT. Fuse Nano Tekno Tekno yang berjumlah 80 karyawan, teknik pengambilan sampel memakai rumus slovin dengan tingkat galat $10 \%$ didapat responden, Teknik pengumpulan data menggunakan uji instrumen data, uji prasyarat data dan uji statistik 


\section{HASIL DAN PEMBAHASAN}

Pembahasan penelitian bertujuan untuk memberikan gambaran dan hasil yang diperoleh penelitian ini. Berdasarkan hasil pengujian secara statistik dapat terlihat bahwa variabel bebas berpengaruh terhadap variabel terikat. Pengaruh yang diberikan oleh variabel bebas bersifat positif yang artinya semakin baik disiplin dan motivasi kerja maka semakin baik pula kinerja karyawan yang dihasilkan.

Pengaruh disiplin dan motivasi kerja terhadap kinerja karyawan pada PT. Fuse Nano Tekno Jakarta Barat dapat dilihat dari hasil uji-uji yang telah dilakukan yaitu:

1. Dari hasil uji normalitas, bahwa nilai kolmogorov lebih besar dari 0,05. Maka dapat disimpulkan bahwa residual berdistribusi secara normal.

2. Dari hasil uji validitas terhadap butir pernyataan variabel $\mathrm{X} 1$ dan $\mathrm{X} 2$, menunjukkan bahwa dinyatakan valid.

3. Dari hasil uji reliabilitas terhadap butir pernyataan variabel $\mathrm{X} 1, \mathrm{X} 2$ dan variabel $Y$, menujukkan bahwa seluruh pernyataan variabel dalam penelitian ini sangat reliabel karena memperoleh angka Cronbach's Alpha $>0,6$.

4. Dari hasil uji korelasi yang telah dilakukan, terjadi hubungan yang sedang antara disiplin kerja terhadap kinerja karyawan PT. Fuse Nano Tekno Jakarta Barat. Hal ini dibuktikan dengan hasil yang menunjukkan angka sebesar 0,600 , sedangkan terjadi hubungan yang kuat antara motivasi dan kinerja karyawan pada PT. Fuse Nano Tekno Jakarta Barat. Hal ini dibuktikan dengan hasil yang menunjukkan angka sebesar 0,612 . Angka tersebut bersifat positif yang berarti semakin tinggi disiplin dan motivasi kerja maka semakin baik pula kinerja karyawan.

5. Dari hasil uji determinasi yang telah dilakukan, besar pengaruh disiplin dan motivasi kerja karyawan adalah sebesar $60 \%$, Sedangkan sisanya yaitu sebesar $40 \%$ dipengaruhi oleh factor lainnya.

6. Dari hasil uji regresi yang telah dilakukan, nilai koefisien regresi disiplin adalah sebesar 0.379 dan nilai koefisien regresi motivasi adalah sebesar 0,351 serta keduanya bernilai positif. Hal ini menunjukkan bahwa semakin baik disiplin dan motivasi kerja pada PT. Fuse Nano Tekno Jakarta Barat, maka kinerja karyawan akan semakin baik.

7. Dari hasil uji multikolinieritas yang telah dilakukan, bahwa nilai tolerance sebesar 2.768. Dapat disimpulkan bahwa tidak ada masalah multikolinieritas antar variabel independen dalam model regresi pada penelitian ini.

\section{PENUTUP \\ Kesimpulan}

Berdasarkan uraian pada bab sebelumnya, dan dari hasil analisis serta pembahasan berikut ini kesimpulannya :

1. Disiplin memiliki pengaruh yang positif dan signifikan terhadap kinerja karyawan pada PT. Fuse Nano Tekno Jakarta Barat. Hal ini dibuktikan dengan melihat jawaban responden dimana dari lima indikator memperoleh total rata-rata responden menyatakan setuju, hal ini terlihat dari jawaban responden yang menyatakan setuju dan sangat setuju sebesar $(50 \%+$ $43 \%)=93 \%$. Hal ini menunjukkan bahwa pendapatresponden mengenai disiplin sudah baik. Berdasarkan hasil statistik dapat diketahui bahwa pengaruh disiplin $\left(\mathrm{X}_{1}\right)$ terhadap kinerja karyawan $(\mathrm{Y})$ adalah 0,800 atau sebesar $60 \%$ sedangkan sisanya $40 \%$ dipengaruhi oleh faktor lain. Hal ini menunjukkan bahwa disiplin yang baik akan meningkatkan kinerja karyawan. Dari pengujian hipotesis diperoleh $\mathrm{t}$ hitung $>\mathrm{t}$ tabel atau $(6,618>0,220)$ sehingga $\mathrm{H}_{0}$ ditolak dan $\mathrm{H}_{1}$ diterima artinya terdapat pengaruh yang positif dan signifikan secara parsial antara disiplin terhadap kinerja karyawan.

2. Motivasi kerja memiliki pengaruh yang posiitif dan signifikan terhadap kinerja karyawan pada PT. Fuse Nano Tekno Jakarta Barat. Hal ini dibuktikan dengan 
jawaban responden yang menyatakan setuju dan sangat setuju sebesar $(50 \%+$ $38 \%)=88 \%$. Hal ini menunjukkan bahwa pendapat responden mengenai motivasi sudah baik. Berdasarkan hasil statistik dapat diketahui bahwa pengaruh motivasi kerja $\left(\mathrm{X}_{2}\right)$ terhadap kinerja karyawan (Y) adalah 0,612 atau sebesar $61,2 \%$ sedangkan sisanya $38,8 \%$ dipengaruhi oleh faktor lain. Hal ini menunjukkan bahwa motivasi kerja yang tinggi akan meningkatkan kinerja karyawan. Dari pengujian hipotesis diperoleh $\mathrm{t}$ hitung $>\mathrm{t}$ tabel atau $(6,827>$ 0,220) sehingga $\mathrm{H}_{0}$ ditolak dan $\mathrm{H}_{1}$ diterima artinya terdapat pengaruh yang positif dan signifikan secara parsial antara motivasi kerja terhadap kinerja karyawan.

3. Berdasarkan hasil penelitian, menunjukkan bahwa disiplin dan motivasi kerja berpengaruh positif terhadap kinerja karyawan di PT. Fuse Nano Tekno Jakarta Barat, dengan persamaan regresi $Y=10,867+0,379\left(X_{1}\right)$ $+0,351\left(X_{2}\right)$. Hasil analisis regresi menunjukkan koefisien disiplin sebesar 0,379 bertanda positif dan motivasi kerja sebesar 0,351. Semakin baik disiplin yang dijalankan maka akan semakin baik pula kinerja karyawan. Demikian pula sebaliknya, disiplin yang dijalankan kurang baik maka kinerja juga akan mengalami penurunan. Demikian pula dengan motivasi kerja. Kontribusi pengaruh disiplin dan motivasi adalah sebesar $63,9 \%$. sehingga $\mathrm{H}_{0}$ ditolak dan $\mathrm{H}_{1}$ diterima. Artinya terdapat pengaruh positif dan signifikan secara simultan antara dsiplin dan motivasi kerja terhadap kinerja karyawan pada PT. Fuse Nano Tekno Jakarta Barat.

\section{Saran}

Berdasarkan hasil penelitian yang telah dilaksanakan, maka saran yang dapat disampaikan sebagai berikut :

1. Meskipun disiplin memiliki pengaruh yang signifikan terhadap kinerja karyawan, namun dari 5 indikator yang ada, indikator yang memperoleh nilai mean score yang paling tinggi adalah sebesar 4,40 dan indikator terendah memiliki nilai mean score 4,12 dengan ketaatan pada standar kerja Karyawan yang mungkin melakukan tindakan yang tidak sopan ke pelanggan atau terlibat dalam tindakan yang tidak pantas merupakan salah satu bentuk tindakan indisipliner. Sehingga saran dari peneliti untuk pihak PT. Fuse Nano Tekno Jakarta Barat, harus meningkatkan kembali ketaatan karyawan terhadap perusahaan.

2. Meskipun motivasi kerja secara memiliki pengaruh yang signifikan terhadap kinerja karyawan namun dari 5 indikator yang ada, indikator yang memperoleh nilai mean score yang paling tinggi adalah sebesar 4,48 dan indikator terendah memiliki nilai mean score 3,91 dengan fasilitas kantor yang kurang memadahi. Sehingga saran dari peneliti untuk pihak PT. Fuse Nano Tekno Jakarta Barat, harus meningkatkan fasilisitas perusahaan sehingga akan terwujudnya suatu pekerjaan atau operational di perusahaan tersebut berjalan dengan baik dan lancar.

3. Kinerja karyawan pada indikator kuantitas pekerjaan dengan memperoleh nilai mean score yang paling tinggi adalah sebesar 4,38 dan indikator terendah memiliki nilai mean score 3,97 dengan alas an atasan yang mengambil keputusan sendiri tanpa melibatakan pendapat atau masukan dari team work. Dengan demikian PT. Fuse Nano Tekno Jakarta Barat, harus meningkatkan kembali kinerja karyawan. 
DAFTAR PUSTAKA

A.A, A. M. (2015). Manajemen Sumber Daya Manusia Perusahaan, Hal 61-93. Bandung: PT.Remaja Rosda Karya.

A.H, M. F., \& David , M. (n.d.). Job Satisfaction Theory.

Abraham, H. M. (2010). Motivation and Personality. Jakarta: Rajawali.

Afandi, P. (2018). MANAJEMEN SUMBER DAYA MANUSIA Teori, Konsep dan Indikato (Edisi 1. Zanafa ed.). Pekanbaru.

Affandi, A., Sarwani, A. S., Erlangga, H., Siagian, A. O., Purwanto, A., Effendy, A. A., ... \& Wahyitno, C. D. M. (2020). Optimization of MSMEs Empowerment in Facing Competition in the Global Market during the COVID-19 Pandemic Time. Systematic Reviews in Pharmacy, 11(11), 1506-1515.

Andi , S. t. (2016). Statistika dalam Kajian Deskriptif, Inferensi, dan Nonparametik. Bandung: Kencana penada media group.

Anwar , P. M. (2015). Manajemen Sumber Daya Manusia Perusahaan. Bandung: PT. Remaja Rosdakarya.

Badriyah, M. (2015). Manajemen Sumber daya Manusia. Bandung: CV Pustaka Setia.

Bangun, W. (2016). Manajemen Sumber Daya Manusia. Jakarta: Erlangga.

Bintoro, d. D. (2017). Manajemen Penilaian Kinerja Karyawan (1 ed.). Yogyakarta: Gava Media.

Dessler, G. (2015). Manajemen Sumber Daya Manusia. Jakarta: Salemba Empat.

Edison, E. d. (2016). Manajemen Sumber Daya Manusia. Bandung: Alfabeta.

Edy, S. (2016). Manajemen Sumber Daya Manusia. Jakarta: Kencana Prenada Media Group.

Ghozali, I. (2016). Aplikasi Analisis Multivariete Dengan Program IBM SPSS Cetakan ke VIII. Semarang: Badan Penerbit Universitas Diponegoro.
Handoko, T. H. (2015). Manajemen Edisi kedua. Yogyakarta: BPFEYogyakarta.

Hasibuan, M. S. (2016). Manajemen Sumber Daya Manusia (Revisi ed.). Jakarta: Penerbit PT Bumi Aksara.

Kristianti, L. S., Affandi, A., Nurjaya, N., Sunarsi, D., \& Rozi, A. (2021). Pengaruh Motivasi Dan Disiplin Kerja Terhadap Kinerja Pegawai Pada Dinas Pariwisata Purwakarta. Jurnal Ilmiah PERKUSI, 1(1), 101-109.

Marwansyah. (2016). Manajemen Sumber Daya Manusia (Dua ed.). Bandung: CV Alfabeta.

McClelland, D. (2015). David McClelland's Motivational Needs Theory. NetMBA.com.

Misbahudin, I. H. (2015). Analisis Data Penelitian Dengan Statistik. Jakarta: Bumi Aksara.

Muchdarsyah, S. (2016). Produktivitas Apa dan Bagaimana. Jakarta: Bumi Aksara.

Nurjaya, N., Affandi, A., Ilham, D., Jasmani, J., \& Sunarsi, D. (2021). Pengaruh Kompetensi Sumber Daya Manusia Dan Kemampuan Pemanfaatan Teknologi Terhadap Kinerja Aparatur Desa Pada Kantor Kepala Desa Di Kabupaten Gunungkidul, Yogyakarta. JENIUS (Jurnal Ilmiah Manajemen Sumber Daya Manusia), 4(3), 332-346.

Paeno, P. (2018). Pengaruh Motivasi dan Disiplin Terhadap Produktivitas Kerja Karyawan Pada PT. Agra Energi Indonesia. JENIUS (Jurnal Ilmiah Manajemen Sumber Daya Manusia), 1(3).

Paramarta, V., Dewi, R. R. V. K., Rahmanita, F., Hidayati, S., \& Sunarsi, D. (2021). Halal Tourism in Indonesia: Regional Regulation and Indonesian Ulama Council Perspective. International Journal of Criminology and Sociology, 10, 497-505.

Priasana, D. J. (2016). Perencanaan \& Pengembangan SDM. Bandung: Alfabeta. 
Sadili , S. (2015). Manajemen Sumber Daya Manusia. Jakarta: CV Pustaka Setia.

Siagian, S. (2015). Manajemen Sumber Daya Manusia. Jakarta: Bumi Aksara.

Sinambela, L. P. (2016). Manajemen Sumber Daya Manusia: Membangun Tim Kerja yang Solid untuk MeningkatkaSn Kinerja. Jakarta: Bumi Aksara.

Sudiarto, S. (2018). Membangun Motivasi Kerja Guru Dalam Menyiapkan Sumber Daya Manusia Indonesia Yang Berkualitas (Analisis Teori Motivasi Abraham Maslow Di SMK Negeri 57 Jakarta). JENIUS (Jurnal Ilmiah Manajemen Sumber Daya Manusia), 1(3).

Sugiyono. (2015). Metode Penelitian Kombinasi (Mix Methods). Bandung: Alfabeta.

Sutrinso, E. (2015). Manajemen Sumber Daya Manusia(Cetakan ke tujuh).
Jakarta: Kencana Prenada Media Group.

Suwatno , \& Donni , J. P. (2016). Manajemen SDM dalam Organisasi Publik dan Bisnis. Bandung: Alfabeta.

Veithzal, R. S. (2015). Manajemen Sumber Daya Manusia Untuk Perusahaan (7 ed.). Depok: PT RAJAGRAFINDO.

Werther, W., \& Keith Davis. (1996). Human Resources And Personal Management (Kelima ed.). New York: McGrawHill.

Wibowo. (2016). Pengaruh Motivasi Kerja terhadap Kinerja Karyawan pada PT. Gramedia Asri Media Cabang Emerald Bintaro. Jakarta: Computech \& Bisnis, 119- 127.

Winardi. (2016). Kepemimpinan dalam Manajemen. Jakarta: PT. Rineka Cipta. 